\title{
Performance vs. Family Ownership and Management: The Case of Portuguese Wine Firms
}

\author{
Luis Pacheco
}

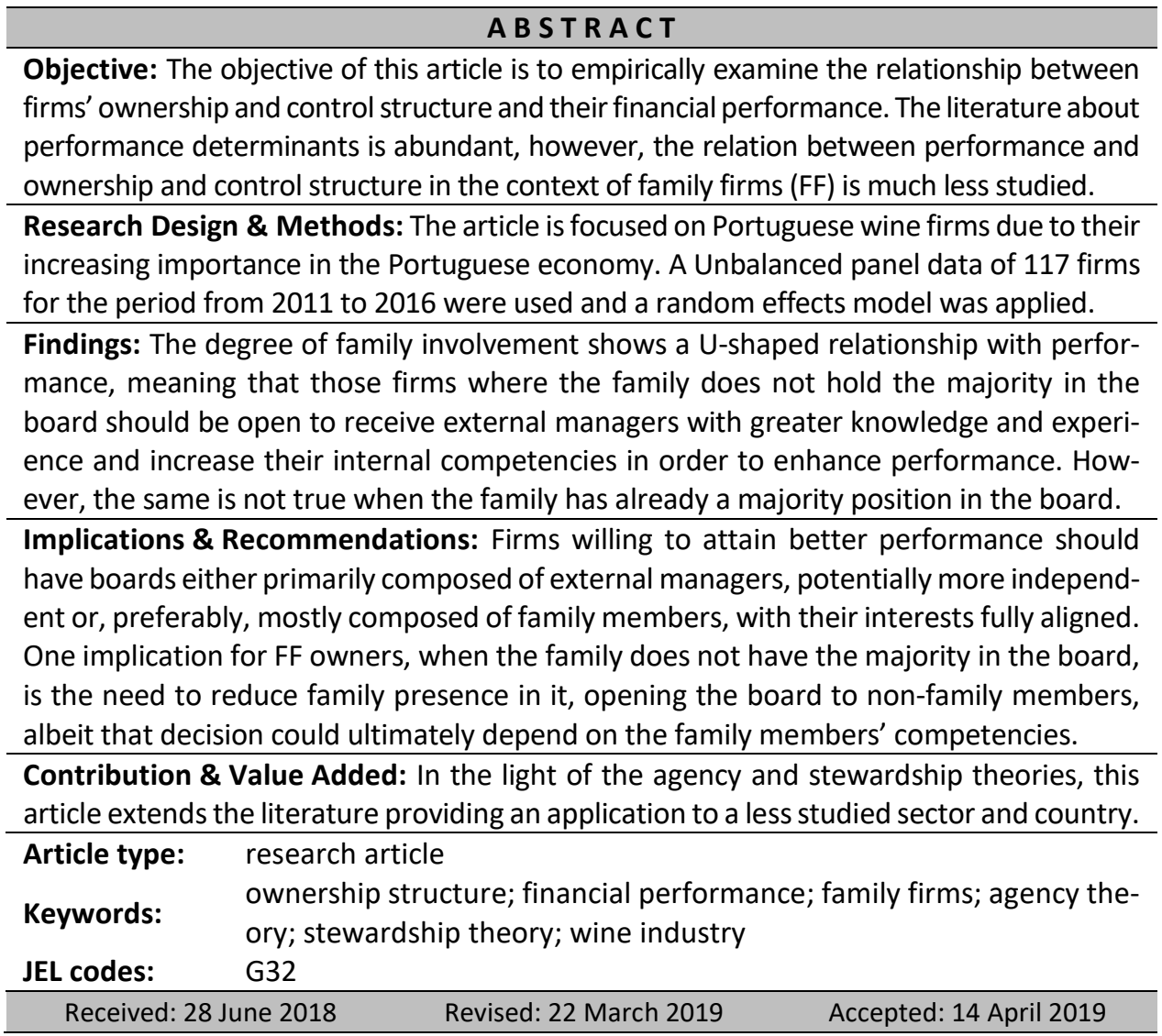

\section{Suggested citation:}

Pacheco, L. (2019). Performance vs. Family Ownership and Management: The Case of Portuguese Wine Firms. Entrepreneurial Business and Economics Review, 7(3), 7-24. https://doi.org/10.15678/EBER.2019.070301 


\section{INTRODUCTION}

In past decades, a considerable number of studies researched how to mitigate agency costs between managers and shareholders, with a fraction of them focused on family firms (FF). Family firms represent a distinctive subset of firms, where family members' ownership, presence and involvement in managerial decisions produce an interesting research topic. Research into FF performance and family's influence in the process of value and wealth creation was boosted by two theoretical papers (Habbershon et al., 2003; Chrisman et al., 2003). The familiness concept refers to the sum of resources and competencies generated by the interaction of family, business and the environment, providing a differentiator factor for firm performance (Sciascia \& Mazzola, 2008; Zellweger et al., 2010). Subsequently, several recent studies have found a significant relationship between $\mathrm{FF}$ and firm performance across countries (e.g., Anderson \& Reeb, 2003; Gama \& Rodrigues, 2013; De Massis et al., 2013; 2015), most of them focused on large and listed firms. Since the results are mixed it is important to contribute to the definition of stylised facts on FF from different countries, because country specific characteristics, such as the legal system, affect FF differently (Bertand \& Schoar, 2006). To the best of our knowledge, with the exception of the recent papers from Vieira (2014; 2017), focused on larger and listed firms, this is the first empirical article examining the relationship between FF and firm performance in Portugal.

Although there is no general consensus on the definition of a FF (Maury, 2006; Villalonga \& Amit, 2006; Kontinen \& Ojala, 2010), such firms can be defined as a business in which members of one or various families share, to a great extent, capital, management responsibilities and the intention of passing the business to future generations. Concerning the definition of a FF, Astrachan et al. (2002) propose the F-PEC model, which identifies a FF regarding its degree of familiness computed as a result of three factors (Power, Experience and Culture). In Portugal, according to the Portuguese Families Businesses Association (www.empresasfamiliares.pt), 70\% to $80 \%$ of Portuguese firms, and probably more than $60 \%$ of GDP and $50 \%$ of employment are ensured by firms "whose property is, total or partially, in the hands of one or more families, with the family having the control over the firm's management."

The wine business in Portugal is a sector where small and predominantly FF coexist with larger and strongly business-focused firms. The wine sector constitutes a source of proud and reputation for Portugal, a country with a high diversity of producing regions, with 31 Protected Designations of Origin and an extraordinary diversity of castes. Wine production and exports in value grew in 2017 for the eighth consecutive year, while the sector also consolidated its position in terms of volume and value in the domestic market. According to the Portuguese Institute of Vine and Wine (www.ivv.min-agricultura.pt), the average annual total production of wine was nearly 7 million hectolitres in 2017, having exported almost 3 million hectolitres with a value of around $€ 778$ million. Portugal is the eleventh world producer, with France, United Kingdom, the United States and Germany being the four main export markets, either in terms of volume or in terms of value. The majority of firms in the sector are familiar and mature firms, where emotional values, the commitment to preserve family assets and succession are relevant issues. Additionally, the sector faces a limited domestic market, a decrease in available land and the need to find 
new customers abroad. All these factors highlight the importance to understand the determinants of firms' financial performance and justify the choice of this sector. Note that these challenges are also faced by wine producers around the globe, so the conclusions from this article could be potentially generalised to other countries.

The objective of this article is to study if FF levels of ownership and control in the Portuguese wine industry have a differentiating impact on their performance. Some control variables are also added to explain performance, namely firm age, size, internationalisation and debt. Considering a representative sample, unbalanced panel data of 117 Portuguese wine SMEs are used for the period from 2011 to 2016, with a total of 697 observations, concluding that family ownership and presence in the board of directors (in a "public limited liability company") or senior management teams (in a "private limited liability company") has a significant, albeit non-linear, positive impact on performance.

The rest of the article is structured as follows. The next section reviews the literature on the relation between family firm performance and the ownership structure and management control. The section also presents the other determinants of performance and the hypotheses to be tested in the article. Section three presents the variables, the data and the methodology to be used. The following section presents and discusses the empirical results with the final section presenting some concluding remarks.

\section{LITERATURE REVIEW}

This article is not strictly focused on the determinants of performance, which is a multidimensional construct heavily researched in the literature (e.g., Venkatraman \& Ramanujam, 1986), but specifically interested in the association between performance and the firm's ownership and control structure. The impact of corporate governance on firms' strategic decision-making and performance has been well documented in the literature (Shleifer \& Vishny, 1986; Villalonga \& Amit, 2006), mostly for large and listed firms, but the idiosyncrasies of family firms and their impact on firms' performance have been less studied. Theories of the relationship between concentrated ownership and firm performance predict positive, negative, or no statistically significant relationship, depending on the trade-offs between the alignment and entrenchment effects (King \& Santor, 2008). Over the past decades, a considerable number of studies researched how to mitigate agency costs between managers and shareholders, with only a fraction of them focused on FF.

Family firms add a dimension to the shareholders vs. managers relation since family members' interests could not be the same as those of their non-family counterparts (Claver et al., 2009; Le Breton-Miller \& Miller, 2009). Also, since often owners in FF are also managers, how would those factors influence performance? FF possess some strengths favouring performance, namely their experience and knowledge of the business, their solid values and group-belonging culture and their long-term perspective (Pukall \& Calabrò, 2014). However, some limitations are succession turbulence, weak organisational structure, lack of professionalism and difficulties in financing (Claver et al., 2009; Le Breton-Miller \& Miller, 2009).

Family firms tend to present higher levels of ownership concentration and thus lower agency conflicts, that being a potentially positive factor for performance (Sciascia \& Mazzola, 2008). Concentrated ownership means higher risk and sunk costs, and increased chances that managers will act in the interest of the owners. In the context of the agency 
theory, non-family managers have the incentive to assume more risky projects (Anderson \& Reeb, 2003). Since the personal wealth of family members is invested in the firm, family controlled firms present higher risk aversion and concerns with survival and transmission to the next generation, so that the effects on performance of the firm's ownership dispersion between family members and their involvement in the firm's managerial decision becomes a relevant topic, though with mixed empirical evidence (Anderson \& Reeb, 2004; Miller et al., 2010; Minichilli et al., 2010).

\section{Ownership Structure and Family Firm Performance}

The disputes concerning performance parallel fundamental disagreements about FF conduct and its social consequences. As stressed by Le Breton-Miller and Miller (2009) and Le Breton-Miller et al. (2011), two perspectives dominate: agency and stewardship. According to the agency theory perspective, FF will be characterised by underinvestment, centralised and hierarchical organisations, cronyism, thus resulting in inferior growth and returns. In contrast, stewardship theory predicts that the investment in capabilities, staff and long-term relationships, the cohesion values and commitments shared with all the stakeholders provide superior growth and financial returns (Davis et al., 1997). Family members act as stewards, strongly identifying with the firm, and working with a superior commitment because they perceive the firm performance as an extension of their own well-being.

Agency theory explains the consequences of the separation of ownership and control (Jensen, 1986; Aggarwal \& Samwick, 2003). The concentration of ownership in a few hands increases the incentives that owners have to monitor managers or giving managers incentives to act according to shareholders' interests (Jensen \& Meckling, 1976). There is substantial evidence that the behaviour of manager-controlled firms is different than the behaviour of owner-controlled firms, thus supporting agency theory. For example, manager-controlled firms are more likely to maximise sales than profits and be more diversified (Amihud \& Kamin, 1979; Amihud \& Lev, 1981), both factors with a potential positive impact on performance. Nevertheless, as pointed by Le Breton-Miller and Miller (2009), some researchers have shown that FF present inferior market valuations (Tobin's q) and financial returns (returns on assets and investment) (e.g., Bennedsen et al., 2007; Claessens et al., 2002; Cronqvist \& Nilsson, 2003), whereas others show that these firms neither outperform nor underperform (Miller et al., 2007). These disagreements appear to be due to the way FF are defined, with founder firms or those with modest firm involvement having an edge over firms with more family owners and more generations (Anderson \& Reeb, 2003; Villalonga \& Amit, 2006).

De Massis et al. (2013) evidence that the agency costs encountered in the decision making process of a FF go beyond the effects due to the degree of family involvement in ownership and management, and depend on the degree of the dispersion of ownership among family members. Specifically, family ownership dispersion has a non-linear effect on performance, this being worse when a moderate number of family members hold equity and higher when family ownership is highly concentrated in the hands of a single family member (thus confirming previous literature defending the presence of non-linearities: e.g., Anderson \& Reeb, 2003; Villalonga \& Amit, 2006; Sciascia \& Mazzola, 2008). When family ownership gets dispersed among few family members, performance could deteriorate due to agency and entrenchment problems arising among equity owners (e.g., conflicts between 
the founder and new family owners), whose interests are not fully aligned with some preferring to pursue private and non-economic returns (Schulze et al., 2003; Sciascia \& Mazzola, 2008). This negative trend on performance is reversed when family ownership is further dispersed among multiple members, who have now only a limited stake in the firm, while it fosters an alignment of interests between equity owners and a reduction of agency costs.

\section{Management Control and Family Firm Performance}

According to Fama and Jensen (1983), combining ownership and control allows concentrated shareholders to exchange profits for private rents (Shleifer \& Vishny, 1997). Thus, FF, which are characterised by concentrated ownership, are condemned to present poor performance (Morck et al., 2000). Although prior literature suggests that family ownership and control can lead to poor firm performance, family influence can also provide competitive advantages, namely, through long-term managerial horizons, the alignment of managers' interests and reputation concerns (Demsetz \& Lehn, 1985; Davis et al., 1997; Anderson et al., 2003).

The implementation of governance structures has shown to be indispensable in FF as the company grows, thus those structures can become a strategic resource, avoiding risks that it may endanger the performance of the firm and thus support its longevity (Gomez-Mejia et al., 2001; Schulze et al., 2001). Structures that unite the ownership and management of firms may help to reduce agency costs. It is expected that through family ties in FF, higher levels of loyalty and mutual trust increase managers' horizons (James, 1999). Nonetheless, this advantage also comes with additional risks when missing hierarchies cannot put governance structures in place. This effect may lead to a situation which encourages the retention of incompetent family staff, while competent employees may leave the firm (De Massis et al., 2008). Dyer (2006) argues as well that professionalisation of a FF is one mean to avoid adverse selection in the company.

The question of whether family presence in the board hinders or facilitates firm performance becomes an empirical issue. In a seminal approach, Anderson and Reeb (2003) evidence that when family members serve as CEO, profitability is higher than with a nonfamily member CEO. In the same vein, Villalonga and Amit (2006) show that performance improves when the founder serves as CEO but decreases when descendants occupy that position, and Maury (2006) shows that active family control is associated with higher profitability compared to NFF. Finally, Chrisman et al. (2004) find that family involvement reduces overall agency costs and increases performance, and Ernst et al. (2012) evidence that family involvement in management seems to be the dominant force in the relation between performance and ownership.

As a result of this literature review, we can now state a first set of hypotheses to be tested:

H1: FF outperform NFF.

H1a: Family ownership has a positive effect on profitability.

H1b: Family involvement in the board has a positive effect on profitability.

H1c: Those effects are non-linear. 


\section{Additional Determinants of Performance}

The present article includes a set of control variables in order to rule out alternative determinants of the sampled firms' performance. Those variables are traditionally used in studies on performance determinants: firm age, size, internationalisation and debt (Sciascia \& Mazzola, 2008; De Massis et al., 2013).

Theoretically, older firms should possess a greater stock of knowledge and experience, which could have a positive impact on performance. So, older firms have enjoyed the benefits of learning, they are not prone to the liabilities of newness and can, therefore, enjoy superior performance. Yet, as firms age they tend to become more conservative and prone to inertia as the influence of the founding entrepreneur is replaced by the next generation (Hannan and Freeman, 1984; Aggarwal and Gort, 1996), albeit in the context of FF it could be precisely that the second generation is responsible for the rebirth of the firm, bringing a more innovative and profitable approach. Therefore, the impact of age on performance is ultimately an empirical question (Coad et al., 2013; Capasso et al., 2015).

Regarding the impact of size on performance, the literature points to the fact that size can be a source of competitive advantage because larger firms have at their disposal greater technical and commercial opportunities, allowing them the access to economies of scale, a greater bargaining power and the capability to raise barriers to deter potential competitors or have an easier access to capital markets (Marcus, 1969; Capon et al., 1990). For instance, Sellers and Alampi-Sottini (2016) evidence a positive and statistically significant relation between firm size and profitability for Italian wine firms. Nevertheless, fixed costs and organisational inefficiencies associated with a larger size could outweigh the benefits of increased market power, with larger flexibility of smaller firms being a competitive advantage (Chen \& Hambrick, 1995) or size could only influence performance in certain industries, given specific differences in terms of the degree of competition or the existence of economies of scale (Marcus, 1969). According to the agency theory, a negative relationship between size and profitability is expected, since the separation of ownership and control creates a conflict between managers and shareholders, which in turn could shift the objective from maximising benefits for others towards management, such as survival or growth. Since those conflicts are less prevalent in the FF environment, a positive relation for those firms could be expected. Nevertheless, the existence of competitive advantages positively related to size also remains an empirical issue.

The discussion of the effects of internationalisation on performance has mainly covered large firms, with the literature generally finding a positive relation between internationalisation and performance (Lu \& Beamish, 2004; Kontinen \& Ojala, 2010; Hsu et al., 2013). Assuming the existence of this positive effect, albeit FF could be more reluctant to expand internationally because of the desire to maintain control and their conservative attitude and lack of resources, we expect a positive impact of internationalisation on performance.

Regarding leverage, some studies show that FF prefer going into debt before increasing capital to finance their investments, thus avoiding the entry of non-family shareholders (Anderson et al., 2003). However, other studies show that FF prefer to be more prudent, not going into debt in order to avoid losing their independence to creditors (López-Garcia \& Aybar-Arias, 2000). Given that FF have specific concerns in terms of privacy, control and 
generational transition, they tend to prefer internal financing policies, favouring the reinvestment of their own funds to a capital increase or long-term debt (Gallo et al., 2004; Zahra, 2005), nevertheless, their attitude towards debt could change as generations, managers and the business as a whole evolves (Lussier \& Sonfield, 2009). According to Miller et al. (2010), FF tend to be more conservative than NFF, trying to minimise risk through investment reductions in R\&D and lower debt levels. So, debt ratios are included because a firm's ownership may influence its capital structure (Demsetz \& Lehn, 1985; Rand $\varnothing$ y \& Goel, 2003) and, in line with the agency and pecking order theories and the majority of the literature, we expect a negative relationship between debt levels and financial performance.

So, regarding the control variables, we state the following set of hypotheses:

H2: The relation between family power and performance differs between younger and older firms, the latter being more profitable.

H3: The relation between family power and performance differs between larger and smaller firms, the former being more profitable.

H4: The relation between family power and performance differs between export oriented and domestically oriented firms, the former being more profitable.

H5: The relation between family power and performance differs between more or less indebted firms, the latter being more profitable.

\section{MATERIAL AND METHODS}

\section{Dependent and Independent Variables}

The use of ROA is widely supported in the literature and has been used in several studies analysing the relationship between familiness and firm performance (e.g., Dyer, 2006; De Massis et al., 2013; Gama \& Rodrigues, 2013; Vieira, 2017), being generally considered to be a key performance indicator of managers and FF in particular (Minichilli et al., 2010). ROA is computed as net income scaled by the book value of total assets. In order to check robustness, we also proxy financial performance as the ratio between EBITDA and total assets (REBITDA) and the ratio between EBIT and total assets (REBIT).

To classify a firm as a FF or not, and due to data availability reasons, we will use two indicators associated to the Power dimension of the F-PEC scale (Astrachan et al., 2002). Firms will be classified as family or non-family according to the family members' percentages of equity ownership and presence in the board:

Family Power (FP) = \% family equity (FAME) + \% family presence (FAMP)

Notice that, depending on the legal form under which the firm operates, there is a board of directors (in a "public limited liability company") or a senior management board (in a "private limited liability company"), albeit here the term "board" is used interchangeably.

For younger firms the determination of those percentages is straightforward, being the family members and their holdings easily identified. However, several generations after, the family expands to include distant relatives whose last names may no longer be the same, so that we resolve descendant issues by examining individual corporate histories and by checking the addresses of the different board members. Following De Massis et al. (2013), besides FP, the variables FAME and FAMP (and their squares) will also be tested individually. Additionally, in alternative to the continuous variable FP, a dummy variable 
will be used to differentiate between FF and NFF. A FF is defined as a firm where the variable FP assumes a value equal or higher than $100 \%$, while those with a lower percentage are classified as NFF. Finally, using a dummy variable it is also tested if the presence of foreign capital has any effect on performance.

\section{Control Variables}

For kurtosis reasons, variables' age (AGE) and size (SIZ) are, respectively, measured as the log of the number of years since the firm's inception and the log of total assets. The debt level of the firm is measured as total debt (TD = Total liabilities/ Total assets) and its subdivision in long-term and short-term debt (respectively, Non-current liabilities/ Total assets and Current liabilities/ Total assets). Concerning the variable "international diversification" (INT), studies reported in the literature the use of different measures, so that a consensus is still lacking on the best or a true measure of international diversification. The use of a uni-dimensional measure such as the ratio of foreign sales to total sales does not take into account the geographical distribution of sales, i.e., whether or not they are geographically well balanced in major world markets. Following Majocchi and Strange (2012), a measure of entropy is used, which accounts for the dispersion of a firm's sales by three main geographical areas (Portugal, the European Union and the rest of the world). Nevertheless, as stated by Majocchi and Strange (2012), such a measure has also some weaknesses: a firm's level of international sales is not expected to be evenly distributed between destiny areas, and an ideal measure of internationalisation should not only measure the dispersion of foreign sales, but also their level. For this reason, the traditional measure of total exports as a percentage of total sales (EXP) is also used.

\section{Data and Methodology}

This article analyses a sample of SMEs from the wine sector (included in the 1102 NACE code - Manufacture of wine), obtained from SABI (Sistema de Análise de Balanços Ibéricos), a financial database powered by Bureau van Dijk. The database includes data for 708 wine sector firms, with a turnover of over $1300 \mathrm{M} €$, total assets of around $3200 \mathrm{M} €$, a mean ROA of $2.66 \%$ and more than nine thousand employees (data for 2016). Applying the criteria for the SME definition, thus excluding a large number of micro firms (which employ fewer than 10 people and whose annual turnover and/or annual balance sheet does not exceed $2 \mathrm{M} €$ ), considering only firms with at least 5 years of complete data from 2011 to 2016 and excluding firms with negative debt ratios or liabilities greater than assets, we obtained unbalanced panel data of 117 SMEs distributed by all Portuguese wine producing regions. Notice that we do not include micro-enterprises with fewer than 10 employees in order to focus on firms that are large enough to experience and demonstrate some managerial decision making as well as family involvement and influence.

The sample is representative for the sector, accounting for 3290 employees, a turnover of around 460M€ and total assets of $1125 \mathrm{M} €$ in 2016. The sample has only 11 mediumsized firms and, applying the criteria explained above, 52 firms can be considered $\mathrm{FF}$, of which 42 have a full measure of "family power." The sample's mean values for the different variables, differentiating between FF and NFF are presented in Table 1, together with the results of a test for differences in mean values between the two sub-samples. Table 1 also presents the correlation matrix of the variables. Notice that FF are significantly better performers than NFF, they are significantly older and smaller, and display a higher degree 
of export diversification. Compared to NFF, FF tend to present lower levels of debt but the differences do not seem to be statistically significant.

A panel data methodology is estimated through three different regression models: Pooled Ordinary Least Squares (POLS), Fixed Effects Model (FEM) and Random Effects Model (REM). Applying the Breusch-Pagan and Hausman tests to choose the most appropriate regression technique, the Breusch-Pagan test leads to the rejection of the null hypothesis, indicating that REM is more appropriate than POLS, whereas the Hausman test leads to the acceptance of the null hypothesis that REM is preferable to FEM. As stated by King and Santor (2008), a random-effects specification seems well suited since a number of our variables are either time-invariant or exhibit few changes over time (e.g., size or family presence).

Table 1. Descriptive statistics (FF and NFF) and the correlation matrix between independent variables

\begin{tabular}{|l|c|c|c|c|c|c|c|c|c|c|}
\hline Variable & $\begin{array}{c}\text { Mean val- } \\
\text { ues (2016) }\end{array}$ & $\begin{array}{c}\text { FF } \\
(\mathbf{n}=\mathbf{5 2})\end{array}$ & $\begin{array}{c}\text { NFF } \\
(\mathbf{n}=\mathbf{6 5})\end{array}$ & $\begin{array}{c}\text { Mean differ. } \\
\text { (t-test) }\end{array}$ & FP & AGE & SIZ & INT & EXP & TD \\
\hline ROA & $1.83 \%$ & $3.61 \%$ & $0.41 \%$ & $5.26\left(^{* * *}\right)$ & & & & & & \\
\hline REBITDA & $6.47 \%$ & $8.56 \%$ & $4.81 \%$ & $5.34\left(^{* * *}\right)$ & & & & & & \\
\hline REBIT & $3.36 \%$ & $5.25 \%$ & $1.85 \%$ & $5.02\left(^{* * *}\right)$ & & & & & & \\
\hline FP & $87.8 \%$ & $194 \%$ & $3 \%$ & & 1 & $\begin{array}{c}0.125 \\
(* * *)\end{array}$ & $\begin{array}{c}-0.176 \\
(* * *)\end{array}$ & $\begin{array}{c}0.078 \\
(* *)\end{array}$ & 0.053 & -0.047 \\
\hline AGE & 3.24 & 3.32 & 3.17 & $3.19(* * *)$ & & 1 & $\begin{array}{c}0.364 \\
(* *)\end{array}$ & $\begin{array}{c}0.153 \\
(* * *)\end{array}$ & $\begin{array}{c}0.166 \\
(* * *)\end{array}$ & $\begin{array}{c}-0.143 \\
(* * *)\end{array}$ \\
\hline SIZ & 8.90 & 8.82 & 8.97 & $-3.80(* * *)$ & & & 1 & $\begin{array}{c}0.151 \\
(* * *)\end{array}$ & $\begin{array}{c}0.129 \\
(* * *)\end{array}$ & $\begin{array}{c}-0.175 \\
(* * *)\end{array}$ \\
\hline INT & 0.59 & 0.64 & 0.57 & $1.80(* * *)$ & & & & 1 & $\begin{array}{c}0.760 \\
(* * *)\end{array}$ & $\begin{array}{c}-0.174 \\
(* * *)\end{array}$ \\
\hline EXP & $33.0 \%$ & $35.3 \%$ & $31.2 \%$ & 1.46 & & & & & 1 & $\begin{array}{c}-0.186 \\
(* * *)\end{array}$ \\
\hline TD & $54.7 \%$ & $53.1 \%$ & $56.1 \%$ & -1.16 & & & & & & 1 \\
\hline LTD & $23.7 \%$ & $20.5 \%$ & $26.3 \%$ & -1.53 & & & & & & \\
\hline STD & $31.0 \%$ & $32.6 \%$ & $29.8 \%$ & 0.37 & & & & & & \\
\hline
\end{tabular}

FF = Family firms; NFF = Non-family firms; ROA = return on assets; REBITDA = ratio between EBITDA and total assets; REBIT = ratio between EBIT and total assets; $F P=$ family power; $A G E=$ logarithm of firm age, in years; $\mathrm{SIZ}=$ firm size, measured by the logarithm of total assets; INT = index of international diversification; EXP = total exports as a percentage of total sales; TD = total debt: LTD = long-term debt; STD = short-term debt. Note: ${ }^{*} \mathrm{p}<0.10 ; * * \mathrm{p}<0.05 ;{ }^{* * *} \mathrm{p}<0.01$.

Source: own study.

\section{RESULTS AND DISCUSSION}

\section{Empirical Results}

The regression results for the random-effects model are presented in Table 2, where the three alternative dependent variables (ROA, REBITDA and REBIT) are run on the variable "family power" (FP) and the control variables AGE, SIZ, internationalisation (INT or EXP) and debt (TD, also divided in LTD and STD). Variables with the suffix FF are interaction variables with the FF dummy, in order to see if the effects of those variables are statisti- 
cally different between FF and NFF, thus testing our hypotheses. Table 3 presents the results for the FF and NFF sub-samples, considering ROA as the independent variable, albeit the results for REBITDA and REBIT are very similar.

Table 2. Random-effects model results

\begin{tabular}{|c|c|c|c|c|c|c|c|c|}
\hline Variable & ROA & REBITDA & REBIT & ROA & ROA & ROA & REBITDA & REBIT \\
\hline C & $\begin{array}{c}-0.001 \\
(0.005) \\
\end{array}$ & $\begin{array}{c}0.045^{* * *} \\
(0.007) \\
\end{array}$ & $\begin{array}{c}0.015^{* * *} \\
(0.006)\end{array}$ & $\begin{array}{l}-0.005 \\
(0.032) \\
\end{array}$ & $\begin{array}{l}-0.004 \\
(0.038) \\
\end{array}$ & $\begin{array}{c}-0.011 \\
(0.031) \\
\end{array}$ & $\begin{array}{c}0.051 \\
(0.036) \\
\end{array}$ & $\begin{array}{c}-0.029 \\
(0.036) \\
\end{array}$ \\
\hline FP & $\begin{array}{c}0.011^{* * *} \\
(0.004) \\
\end{array}$ & $\begin{array}{c}0.013 * * * \\
(0.005) \\
\end{array}$ & $\begin{array}{c}0.012^{* * *} \\
(0.005)\end{array}$ & $\begin{array}{c}0.012^{* * *}(0.004) \\
\end{array}$ & $\begin{array}{c}0.001 \\
(0.020) \\
\end{array}$ & $\begin{array}{c}0.013^{* * *} \\
(0.004) \\
\end{array}$ & $\begin{array}{c}0.016^{* * *}(0.005) \\
\end{array}$ & $\begin{array}{c}0.015^{* * *} \\
(0.004)\end{array}$ \\
\hline \multicolumn{9}{|l|}{ Controls } \\
\hline AGE & & & & $\begin{array}{c}-0.010^{* *} \\
(0.004) \\
\end{array}$ & $\begin{array}{c}0.000 \\
(0.001) \\
\end{array}$ & \begin{tabular}{|c|}
$-0.009 * *$ \\
$(0.004)$ \\
\end{tabular} & $\begin{array}{c}-0.016 * * * \\
(0.005) \\
\end{array}$ & \begin{tabular}{|c}
$-0.012^{* *}$ \\
$(0.005)$ \\
\end{tabular} \\
\hline$S I Z$ & & & & $\begin{array}{c}0.009 * * \\
(0.004) \\
\end{array}$ & $\begin{array}{c}0.004 \\
(0.005) \\
\end{array}$ & $\begin{array}{c}0.010^{* * *} \\
(0.004) \\
\end{array}$ & $\begin{array}{c}0.011^{* *} \\
(0.004) \\
\end{array}$ & $\begin{array}{c}0.014 * * * \\
(0.004) \\
\end{array}$ \\
\hline INT & & & & $\begin{array}{c}0.008 \\
(0.005) \\
\end{array}$ & & & & \\
\hline EXP & & & & & $\begin{array}{l}-0.004 \\
(0.011) \\
\end{array}$ & $\begin{array}{l}-0.003 \\
(0.008) \\
\end{array}$ & & \\
\hline TD & & & & $\begin{array}{c}-0.083^{* * *} \\
(0.011) \\
\end{array}$ & & & & \\
\hline LTD & & & & & $\begin{array}{c}-0.055^{* * * *} \\
(0.015) \\
\end{array}$ & $\begin{array}{c}-0.090 * * * \\
(0.012)\end{array}$ & $\begin{array}{c}-0.095 * * * \\
(0.014)\end{array}$ & $\begin{array}{c}-0.084 * * * \\
(0.013) \\
\end{array}$ \\
\hline STD & & & & & $\begin{array}{c}-0.050^{* * *} \\
(0.015) \\
\end{array}$ & $\begin{array}{c}-0.076^{* * *} \\
(0.012) \\
\end{array}$ & $\begin{array}{c}-0.085 * * * \\
(0.014) \\
\end{array}$ & $\begin{array}{c}-0.073 * * * \\
(0.014) \\
\end{array}$ \\
\hline AGE_FF & & & & & \begin{tabular}{|c|}
$-0.023^{* *}$ \\
$(0.009)$ \\
\end{tabular} & & & \\
\hline SIZ_FF & & & & & $\begin{array}{c}0.016^{* * *} \\
(0.005) \\
\end{array}$ & & & \\
\hline EXP_FF & & & & & $\begin{array}{c}0.005 \\
(0.018) \\
\end{array}$ & & & \\
\hline LTD_FF & & & & & $\begin{array}{c}-0.092 * * * \\
(0.024)\end{array}$ & & & \\
\hline STD_FF & & & & & \begin{tabular}{|c|}
$-0.062^{* *}$ \\
$(0.025)$ \\
\end{tabular} & & & \\
\hline Overall $R^{2}$ & 0.04 & 0.04 & 0.04 & 0.20 & 0.23 & 0.20 & 0.22 & 0.18 \\
\hline
\end{tabular}

Notes: Standard-deviations presented in brackets. ${ }^{*} \mathrm{p}<0.10 ;{ }^{* *} \mathrm{p}<0.05 ;{ }^{* * *} \mathrm{p}<0.01$.

Source: own study.

With the full specification the random-effects model results present a goodness of fit near $20 \%$. Albeit not presented, the presence of foreign capital did not show a significant effect on performance. Since one of the objectives of this article is to test the presence of non-linear effects of familiness on performance, we alternatively test the variables FP, "family ownership" (FAME), "family presence" (FAMP) and their squares as independent variables (Table 4). Notice that results for FAME are not presented since they are not significant. 
Table 3. Random-effects model results: FF and NFF sub-samples (ROA as dependent variable)

\begin{tabular}{|l|c|c|}
\hline \multicolumn{1}{|c|}{ Variable } & FF & NFF \\
\hline \multirow{2}{*}{ C } & -0.048 & 0.038 \\
& $(0.048)$ & $(0.039)$ \\
\hline \multirow{2}{*}{ AGE } & $-0.021^{* * *}$ & 0.001 \\
& $(0.007)$ & $(0.005)$ \\
\hline \multirow{2}{*}{ SIZ } & $0.024^{* * *}$ & -0.001 \\
& $(0.006)$ & $(0.005)$ \\
\hline \multirow{2}{*}{ EXP } & 0.001 & -0.005 \\
& $(0.015)$ & $(0.010)$ \\
\hline \multirow{2}{*}{ LTD } & $-0.146^{* * *}$ & $-0.059^{* * *}$ \\
& $(0.020)$ & $(0.014)$ \\
\hline \multirow{2}{*}{ STD } & $-0.107^{* * *}$ & $-0.055^{* * *}$ \\
& $(0.021)$ & $(0.014)$ \\
\hline Overall $\boldsymbol{R}^{\mathbf{2}}$ & $\mathbf{0 . 2 7}$ & $\mathbf{0 . 0 9}$ \\
\hline
\end{tabular}

Notes: Standard-deviations presented in brackets.

$* \mathrm{p}<0.10 ; * * \mathrm{p}<0.05 ; * * * \mathrm{p}<0.01$.

Source: own study.

Table 4. Random-effects model results: Testing the presence of non-linearities

\begin{tabular}{|c|c|c|c|c|c|c|}
\hline Variable & ROA & REBITDA & REBIT & ROA & REBITDA & REBIT \\
\hline C & $\begin{array}{c}0.000 \\
(0.005)\end{array}$ & $\begin{array}{c}0.047^{* * *} \\
(0.007)\end{array}$ & $\begin{array}{c}0.016^{* *} \\
(0.006)\end{array}$ & $\begin{array}{c}0.001 \\
(0.005)\end{array}$ & $\begin{array}{c}0.048^{* * *} \\
(0.007)\end{array}$ & $\begin{array}{c}0.017^{* * *} \\
(0.006)\end{array}$ \\
\hline FP & $\begin{array}{l}-0.014 \\
(0.041)\end{array}$ & $\begin{array}{c}-0.041 \\
(0.051)\end{array}$ & $\begin{array}{c}-0.024 \\
(0.047)\end{array}$ & & & \\
\hline $\mathrm{FP}^{2}$ & $\begin{array}{c}0.012 \\
(0.020)\end{array}$ & $\begin{array}{c}0.027 \\
(0.026)\end{array}$ & $\begin{array}{c}0.018 \\
(0.024)\end{array}$ & & & \\
\hline FAMP & & & & $\begin{array}{l}-0.206 \\
(0.131)\end{array}$ & $\begin{array}{c}-0.337^{* * *} \\
(0.163)\end{array}$ & $\begin{array}{c}-0.303 * * \\
(0.151)\end{array}$ \\
\hline FAMP2 & & & & $\begin{array}{l}0.226^{*} \\
(0.131)\end{array}$ & $\begin{array}{c}0.361^{* *} \\
(0.163)\end{array}$ & $\begin{array}{c}0.324^{* *} \\
(0.150)\end{array}$ \\
\hline Overall $R^{2}$ & 0.04 & 0.05 & 0.04 & 0.02 & 0.07 & 0.06 \\
\hline
\end{tabular}

Notes: Standard-deviations presented in brackets. ${ }^{*} p<0.10 ;{ }^{* *} p<0.05 ;{ }^{* *} p<0.01$.

Source: own study.

\section{Discussion}

We now analyse the results at the light of the different hypotheses. The first rows in Table 2 evidence that "family power" (ownership and presence in the board) seems to have a positive impact on performance thus confirming $\mathrm{H} 1 \mathrm{a}$ and $\mathrm{H} 1 \mathrm{~b}$ and the results from $\mathrm{An}$ derson and Reeb (2003), King and Santor (2008), De Messis et al. (2013) and Gama and Rodrigues (2013). Notice that albeit the results are not presented, the regressions were also run with FAME and FAMP instead of FP, yielding extremely similar results.

Regarding the possibility of a non-linear relationship, the results presented in Table 4 show that family presence in the board displays a significant U-shaped relation with performance. Figure 1 plots this important result, showing that, after obtaining decreasing profits as the firm board is increasingly opened to family members, higher performance is attained when the whole management team is made up of family members. The inflection point is 
found for family presence values slightly lower than $47 \%$, that is, firms where the board is more or less divided between family and non-family members. This result, which partially confirms $\mathrm{H} 1 \mathrm{c}$, evidences apotential negative influence on the performance of conflicts and misalignment of interests within the board. Beyond a certain point, the advantages coming from decreasing agency costs and stewardship outweigh the disadvantages of conflicts between board members and overlap between family and business interests.

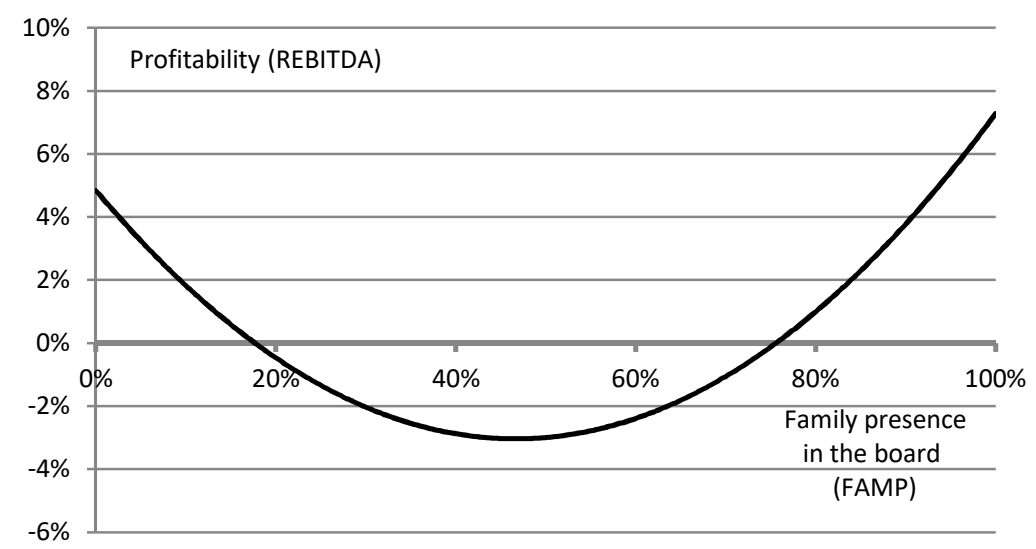

Figure 1. The effect of family presence in the board on performance Source: own elaboration.

The quadratic nature of the relationship between family involvement in management and performance calls for major attention to these effects by FF owners who must acknowledge that family presence in the board brings dysfunctional consequences for firm performance, especially at intermediate levels of family involvement, where members external to the family could eventually have been selected based on personal contacts, disregarding personal managerial capabilities. So, it seems that in the wine sector family SMEs a robust and majority presence of the family in the board is value enhancing and promotes their financial performance.

Regarding the other hypotheses, the interaction terms are broadly significant, showing different impacts of AGE, SIZ, LTD and STD on performance for FF and NFF, which gives support to H3 and H5. Similarly to Vieira (2014) and Capasso et al. (2015), the firm's age seems to have a negative impact on performance, thus not confirming $\mathrm{H} 2$. Possibly, older firms are more likely to be in the maturity phase, with lower levels of growth opportunities and, consequently, lower financial performance levels. Also, the results for FF confirm H3, with larger firms presenting a better financial performance, possibly a result of the positive relationship between resources and performance. This evidence that bigger firms outperform smaller ones brings an important policy-making implication. Typically, wine firms in Portugal are micro or small firms, so policymakers should create an adequate set of incentives to foster mergers and acquisitions in the sector, as a way to improve the competitiveness of the entire wine sector. Contrary to Sciascia and Mazzola (2008), the results regarding the internationalisation degree are always not significant, whereas in terms of international diversification 
or exports as a percentage of sales. Thus, $\mathrm{H} 4$ is not confirmed, suggesting that the wine sector's performance is not influenced by the degrees of international intensity and diversification. Notice that the literature about the influence of family ownership on internationalisation provides conflicting results, with Zahra (2003) and Chen et al. (2014) empirically supporting a positive influence, whereas Fernández and Nieto $(2005 ; 2006)$ or Wach (2017) point to a negative relation. Finally, $\mathrm{H} 5$ is strongly confirmed for all firms, since more indebted firms are less profitable, independently of the maturity of the debt. This result, which is typically found in the literature, is in line with the predictions of the agency and pecking theories, since a high level of leverage imposes a fixed financial commitment on the firm, reducing the free cash flows available to management (Vieira, 2017). Specifically regarding $\mathrm{FF}$, a negative relation could be explained by the family's concerns with increased levels of financial risk and fears of losing control (Zahra, 2005).

\section{CONCLUSIONS}

Management theories should not consider firms just as a value maximising entity regardless of its owners. Different owners and managers have different risk attitudes, face different incentives and bring different resources to the firm, so similar firms, pertaining to the same sector, could present different degrees of performance. To date, at the light of the agency and stewardship theories, little empirical research has been conducted to identify the variables that promote FF financial performance.

This exploratory article contributes to filling that gap by studying the differences between FF and NFF in terms of financial performance. The degree of family ownership and involvement showed a significant positive relationship with performance, meaning that those FF in which the owner family exerts tighter control tend to present higher measures of performance, thus confirming previous results. That non-linear relation indicates that firms willing to attain better performance should have boards either primarily composed of external managers, potentially more independent or, preferably, mostly composed of family members, with their interests fully aligned. One implication for FF owners, when the family does not have the majority in a mixed board, is the need to further reduce family presence in it, opening the board to non-family members whose skills and capabilities could add value to the firm. That difficult decision could prove more profitable than a further increase in the presence of family members in the board. However, the same is not true when the family has already a majority position in the board, since better financial performance is attained when the family totally controls the management team.

Regarding the main questions addressed in this article, we can answer that: i) compared to other firms, FF are more profitable, but ii) performance is negatively impacted by intermediate degrees of family presence in the board; iii) there is a significant positive relation between firm size and performance, a significant negative impact of firm age on performance and the degree of internationalisation is irrelevant to explain differences in performance; iv) and, finally, there is a significant negative relation between the level of debt and performance.

This article gives a twofold contribution to the literature about FF, studying if there are significant differences between FF and NFF in terms of performance and improving the limited literature on performance for FF in a specific sector. Nevertheless, some limitations of this study should be mentioned: i) in the first place, firms' performance is affected by 
many variables that were not considered (e.g., managerial labour and product markets, political and economic factors or even the personality of shareholders and managers), meaning that the results should be treated with caution; ii) secondly, the concept of FF used in the literature is not homogeneous, being normally used a dichotomous characterisation. Other authors present different measures, possibly explaining some of the different results found; iii) third, the dataset comprises 117 firms, representing roughly one third of the Portuguese wine sector. Ideally, a larger number of observations and firms could result in more robust results. Notice that firms under analysis are the firms that survived a period of fierce competition, mergers and emergence of new players in the sector; iv) finally, a factor that can limit the generalisation of the results is that the study focuses only on the Portuguese wine sector. Also, the measures of performance used in the literature differ widely, leaving us with the question whether our results are dependent on the three measures used and on the specific context of the Portuguese wine firms. It would be interesting to study the presence of the U-shaped relation in other sectors, trying to unveil if it constitutes a particularity of the wine sector or not, a sector where firms traditionally cultivate a sense of commitment, social-emotional values and a long-term view among all stakeholders. Nevertheless, the limitations of the internal market and the small size of firms are characteristics also present in other wine-exporting countries, so our conclusions could perfectly be applied to other countries.

Analysing our main results through the light of the agency and stewardship theories, we can argue that increased family control silences any voices that could disrupt the necessary harmony to attain better performance. Nevertheless, our results call for further research, suggesting that firm performance depends heavily on other factors. So, further research should, inter alia, (i) introduce qualitative variables, for instance, consider internal factors such as succession issues, product positioning, marketing and brand management and the firm's specific resources, namely, the impact on performance of the family members' levels of social capital and education; (ii) further research into the relationship between performance and the ownership and control structure, covering a longer period and studying the wine sector in other European countries; iii) analyse in a case by case approach in order to identify the types of management practice currently being implemented by Portuguese wine firms that have a positive impact on performance.

\section{REFERENCES}

Aggarwal, R., \& Gort, M. (1996). The evolution of markets and entry, exit and survival of firms. The Review of Economics and Statistics, 78(3), 489-498.

Aggarwal, R., \& Samwick, A. (2003). Why do managers diversify their firms? Agency reconsidered. Journal of Finance, 58(1), 71-118.

Amihud, Y., \& Kamin, J. (1979). Revenue vs. profit maximization: Differences in behavior by the type of control and by market power. Southern Economic Journal, 45(3), 838-846.

Amihud, Y., \& Lev, B. (1981). Risk reduction as a managerial motive for conglomerate mergers. Bell Journal of Economics, 12(2), 605-617.

Anderson, R., Mansi, S., \& Reeb, D. (2003). Founding family ownership and the agency cost of debt. Journal of Financial Economics, 68(2), 263-285. 
Anderson, R., \& Reeb, D. (2003). Founding-family ownership and firm performance: Evidence from the S\&P500. Journal of Finance, 58(3), 1321-1328.

Anderson, R., \& Reeb, D. (2004). Board composition: Balancing family influence in S\&P 500 firms. Administrative Science Quarterly, 49(2), 209-237.

Astrachan J., Klein, S., \& Smyrnios, K. (2002). The F-PEC scale of family influence: A proposal for solving the family business definition problem. Family Business Review, 15(1), 45-58.

Bennedsen, M., Nielsen, K.M., Pérez-González, F., \& Wolfenzon, D. (2007). Inside the family firm: The role of families in succession decisions and performance. The Quarterly Journal of Economics, 122(2), 647-691.

Bertrand, M., \& Schoar, A. (2006). The role of family in family firms. The Journal of Economic Perspectives, 20(2), 73-96.

Capasso, A., Gallucci, C., \& Rossi, M. (2015). Standing the test of time: Does firm performance improve with age? An analysis of the wine industry. Business History, 57(7), 1037-1053.

Capon, N., Farley, J., \& Hoenig, S. (1990). Determinants of financial performance: a meta-analysis. Management Science, 36(10), 1143-1159.

Chen, M., \& Hambrick, D. (1995). Speed, stealth, and selective attack: How small firms differ from large firms in competitive behavior. Academy of Management Journal, 38(2), 453-482.

Chen, H., Hsu, W., \& Chang, C. (2014). Family ownership, institutional ownership, and internationalization of SMEs. Journal of Small Business Management, 52(4), 771-789.

Chrisman, J., Chua, J., \& Litz, R. (2003). A unified systems perspective of family firm performance: An extension and integration. Journal of Business Venturing, 18(4), 467-472.

Chrisman, J., Chua, J., \& Litz, R. (2004). Comparing the agency costs of family and non-family firms: Conceptual issues and exploratory evidence. Entrepreneurship Theory and Practice, 28(4), 335-354.

Claessens, S., Djankov, S., Fan, J., \& Lang, L. (2002). Disentangling the incentive and entrenchment effects of large shareholdings. Journal of Finance, 57(6), 2741-2771.

Claver, E., Rienda, L., \& Quer, D. (2009). Family firms' international commitment: The influence of family-related factors. Family Business Review, 22(2), 125-135.

Coad, A., Segarra, A., \& Teruel, M. (2013). Like milk or wine: Does firm performance improve with age?. Structural Change and Economic Dynamics, 24, 173-189.

Cronqvist, H., \& Nilsson, M. (2003). Agency costs of controlling minority shareholders. Journal of Financial and Quantitative Analysis, 38(4), 695-719.

Davis, J., Schoorman, F., \& Donaldson, L. (1997). Toward a stewardship theory of management. Academy of Management Review, 22(1), 20-47.

De Massis, A., Chua, J., \& Chrisman, J. (2008). Factors preventing intra-family succession. Family Business Review, 21(2), 183-199.

De Massis, A., Kotlar, J., Campopiano, G., \& Cassia, L. (2013). Dispersion of family ownership and the performance of small-to-medium size private family firms. Journal of Family Business Strategy, 4(3), 166-175.

De Massis, A., Kotlar, J., Campopiano, G., \& Cassia, L. (2015). The impact of family involvement on SMEs' performance: Theory and evidence. Journal of Small Business Management, 53(4), 924-948.

Demsetz, H., \& Lehn, K. (1985). The structure of corporate ownership: Causes and consequences. Journal of Political Economy, 93(6), 1155-1177.

Dyer, W. (2006). Examining the "family effect" on firm performance. Family Business Review, 19(4), 253-273. 
Ernst, J., Kraus, S., \& Matser, I. (2012). The relation between performance and family involvement an exploration into the non-linear effects during the life-stage of Dutch firms. International Journal of Entrepreneurship and Innovation Management, 15(3), 198-215.

Fama, E., \& Jensen, M. (1983). Separation of ownership and control. The Journal of Law and Economics, 26(2), 301-325.

Fernández, Z., \& Nieto, M. (2005). Internationalization strategy of small and medium-sized family businesses: Some influential factors. Family Business Review, 18(1), 77-89.

Fernández, Z., \& Nieto, M. (2006). Impact of ownership on the international involvement of SMEs. Journal of International Business Studies, 37(3), 340-351.

Gallo, M., Tàpies, J., \& Cappuyns, K. (2004). Comparison of family and non family business: Financial logic and personal preferences. Family Business Review, 17(4), 303-318.

Gama, A., \& Rodrigues, C. (2013). The governance-performance relations in publicly listed family controlled firms: An empirical analysis. Corporate Governance: The International Journal of Business in Society, 13(4), 439-456.

Gomez-Mejia, L., Nunez-Nickel, M., \& Gutierrez, I. (2001). The role of family ties in agency contracts. Academy of Management Journal, 44(1), 81-95.

Habbershon, T., Williams, M., \& MacMillan, I. (2003). A unified systems perspective of family firm performance. Journal of Business Venturing, 18(4), 451-465.

Hannan, M. \& Freeman, J. (1984). Structural inertia and organizational change. American Sociological Review, 49(2), 149-164.

Hsu, W., Chen, H., \& Cheng, C. (2013). Internationalization and firm performance of SMEs: The moderating effects of CEO attributes. Journal of World Business, 48(1), 1-12.

James, H. (1999). Owner as manager, extended horizons and the family firm. International Journal of the Economics of Business, 6(1), 41-55.

Jensen, M. (1986). Agency costs of free cash flow, corporate finance and takeover. American Economic Review, 76, 323-329.

Jensen, M., \& Meckling, W. (1976). Agency costs and the theory of the firm. Journal of Financial Economics, 3(4), 305-360.

King, M., \& Santor, E. (2008). Family values: Ownership structure, performance and capital structure of Canadian firms. Journal of Banking and Finance, 32(11), 2423-2432.

Kontinen, T., \& Ojala, A. (2010). The internationalization of family businesses: A review of extant research. Journal of Family Business Strategy, 1(2), 97-107.

Le Breton-Miller, I., \& Miller, D. (2009). Agency vs. stewardship in public family firms: A social embeddedness reconciliation. Entrepreneurship Theory and Practice, 33(6), 1169-1191.

Le Breton-Miller, I., Miller, D., \& Lester, R. (2011). Stewardship or agency? A social embeddedness reconciliation of conduct and performance in public family businesses. Organization Science, 22(3), 704-721.

López-Garcia, J., \& Aybar-Arias, C. (2000). An empirical approach to the financial behaviour of small and medium sized companies. Small Business Economics, 14(1), 55-63.

Lu, J., \& Beamish, P. (2004). International diversification and firm performance: The S-curve hypothesis. Academy of Management Journal, 47(4), 598-609.

Lussier, R., \& Sonfield, M. (2009). Founder influences in family businesses: Analyzing combined data from six diverse countries. Journal of Small Business Strategy, 20(1), 103-118. 
Majocchi, A., \& Strange, R. (2012). International diversification: The impact of ownership structure, the market for corporate control and board independence. Management International Review, 52(6), 879-900.

Marcus, M. (1969). Profitability and size of firm: Some further evidence. The Review of Economics and Statistics, 51(1), 104-107.

Maury, B. (2006). Family ownership and firm performance: Empirical evidence from Western European corporations. Journal of Corporate Finance, 12(2), 321-341.

Miller, D., Le Breton-Miller, I., Lester, R., \& Cannella, A. (2007). Are family firms really superior performers?. Journal of Corporate Finance, 13(5), 829-858.

Miller, D., Le Breton-Miller, I., \& Lester, R. (2010). Family and lone founder ownership and strategic behaviour: Social context, identity, and institutional logics. Journal of Management Studies, 48(1), 1-25.

Minichilli, A., Corbetta, G., \& MacMillan, I. (2010). Top management teams in family-controlled companies: 'Familiness', 'faultlines', and their impact on financial performance. Journal of Management Studies, 47(2), 205-222.

Morck, R., Nakamura, M., \& Shivdasani, A. (2000). Banks, ownership structure, and firm value in Japan. The Journal of Business, 73(4), 539-567.

Pukall, T., \& Calabrò, A. (2014). The Internationalization of Family Firms: A critical review and integrative model. Family Business Review, 27(2), 103-125.

Randøy, T., \& Goel, S. (2003). Ownership structure, founder leadership, and performance in Norwegian SMEs: Implications for financing entrepreneurial opportunities. Journal of Business Venturing, 18(5), 619-637.

Schulze, W., Lubatkin, M., Dino, R., \& Buchholtz, A. (2001). Agency relationships in family firms: Theory and evidence. Organization Science, 12(2), 99-116.

Schulze, W., Lubatkin, M., \& Dino, R. (2003). Toward a theory of agency and altruism in family firms. Journal of Business Venturing, 18(4), 473-490.

Sciascia, S., \& Mazzola, P. (2008). Family involvement in ownership and management: Exploring nonlinear effects on performance. Family Business Review, 21(4), 331-345.

Sellers, R., \& Alampi-Sottini, V. (2016). The influence of size on winery performance: Evidence from Italy. Wine Economics and Policy, 5(1), 33-41.

Shleifer, A., \& Vishny, R. (1986). Large shareholders and corporate control. The Journal of Political Economy, 94(3-1), 461-488.

Shleifer, A., \& Vishny, R. (1997). A survey of corporate governance. Journal of Finance, 52, 737-783.

Venkatraman, N., \& Ramanujam, V. (1986). Measurement of business performance in strategy research: A comparison of approaches. Academy of Management Review, 11(4), 801-814.

Vieira, E. (2014). The effect on the performance of listed family and non-family and non-family firms. Managerial Finance, 40(3), 234-253.

Vieira, E. (2017). Debt policy and firm performance of family firms: The impact of economic adversity. International Journal of Managerial Finance, 13(3), 267-286.

Villalonga, B., \& Amit, R. (2006). How do family ownership, control and management affect firm value?. Journal of Financial Economics, 80(2), 385-417.

Wach, K. (2017). Exploring the role of ownership in international entrepreneurship: How does ownership affect internationalisation of Polish firms?. Entrepreneurial Business and Economics Review, 5(4), 205-224. 
Zahra, S. (2003). International expansion of US manufacturing family businesses: The effect of ownership and involvement. Journal of Business Venturing, 18(4), 495-512.

Zahra, S. (2005). Entrepreneurial risk taking in family firms. Family Business Review, 18(1), 23-40.

Zellweger, T., Eddleston, K., \& Kellermanns, F. (2010). Exploring the concept of familiness: Introducing family firm identity. Journal of Family Business Strategy, 1(1), 54-63.

\section{Author}

\section{Luís Pacheco}

PhD in Economics from the Technical University of Lisbon, MSc in Monetary and Financial Economics and a Degree in Economics. University lecturer since 1994, with the responsibility of teaching at undergraduate and master degrees in the financial and economical area. Research activity in the financial - capital structure, markets and financial products, etc. - and tourism area - factors of satisfaction, hospitality, etc. - publishing papers in several national and international scientific journals.

Correspondence to: Prof. Luís Pacheco; Portucalense University; Department of Economics and Management; Rua Dr. António Bernardino de Almeida, 541, 4200-072 Porto, Portugal; e-mail: luisp@upt.pt

ORCID (1) http://orcid.org/0000-0002-9066-6441

\section{Acknowledgements and Financial Disclosure}

This work is supported by FEDER funds from COMPETE 2020 and Portuguese funds - PORTUGAL 2020. Project IECPBI - Interactive Ecosystem for Portuguese Business Internationalization - POCI01-0145-FEDER-032139.

\section{Copyright and License}

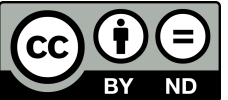

This article is published under the terms of the Creative Commons Attribution - NoDerivs (CC BY-ND 4.0) License http://creativecommons.org/licenses/by-nd/4.0/

\section{Published by the Centre for Strategic and International Entrepreneurship - Krakow, Poland}

